\title{
What Price Style? The Fabric-Advisory Function of the Drygoods Commission Merchant, 1850-1880
}

\author{
Siegenthaler, Hansjörg
}

\begin{abstract}
Using data from nineteenth-century New England, Dr. Siegenthaler isolates a value for the most important function which drygoods marketing agencies performed for the mills they represented. His conclusions cast new light on the key role played by fashion considerations in decision making within the textile industry
\end{abstract}

DOI: https://doi.org/10.2307/3112420

Posted at the Zurich Open Repository and Archive, University of Zurich ZORA URL: https://doi.org/10.5167/uzh-154928

Journal Article

Published Version

Originally published at:

Siegenthaler, Hansjörg (1967). What Price Style? The Fabric-Advisory Function of the Drygoods Commission Merchant, 1850-1880. Business History Review, 41(01):36-61.

DOI: https://doi.org/10.2307/3112420 


\title{
What Price Style? The Fabric-Advisory Function of the Drygoods Commission Merchant, 1850-1880
}

\begin{abstract}
I Using data from nineteenth-century New England, Dr. Siegenthaler isolates a value for the most important function which drygoods marketing agencies performed for the mills they represented. His conclusions cast new light on the key role played by fashion considerations in decision making within the textile industry.
\end{abstract}

It is well known that mid-nineteenth-century New England textile mills paid a good deal of money for the services of the drygoods commission houses which marketed their products. A large cotton mill with a wholesale value of output of $\$ 1,000,000$ per year spent at least $\$ 15,000$ per year on commissions. In comparison, the same corporation paid its top manager, the treasurer, a yearly salary of $\$ 5,000$ to $\$ 7,000$ for general supervision of operations and finance, for buying stock, and for dealing with labor problems; its top technician, the mill superintendent, was paid a salary of less than $\$ 5,000$ per year to supervise production. ${ }^{1}$

The relative share of total expenditures on managerial services which went to the marketing agency was thus large and indicates that the latter furnished a valuable bundle of relatively scarce services. It is the object of this paper to show that, indeed, the bundle of services provided by the marketing agency was crucial to the success of the mill; and to show that the one service of outstanding importance was the giving of advice on the choice of fabrics to be produced.

Choice of fabrics to be produced was a decision of increasing

Business History Review, Vol. XLI, No. 1 (Spring, 1967). (O The President and Fellows of Harvard College.

\footnotetext{
I For the commission payments see, e.g., Report of Mr. William Sturgis' Committee to Twenty-eight Manufacturing Companies (Boston, 1852), Appendix. For salaries: John S. Ewing and Nancy P. Norton, Broadlooms and Businessmen: A History of the Bigelow-Sanford Carpet Company (Cambridge, Mass., 1955), 75, 107; James C. Ayer, Some of the Usages and Abuses in the Management of Our Manufacturing Corporations (Lowell, Mass., 1863), 13; Memorandum of Certain Commissions \& Salaries Paid by Manuf' Co's, August 1, 1848, Amos A. Lawrence Papers (Massachusetts Historical Society, Boston).
} 
importance in the textile industry, from the middle of the nineteenth century to the $1880^{\circ}$ 's. The spread of technical knowledge and skill and easier access to the technical equipment with the development of a textile-machinery industry led to increasing competitive pressure in the 1840 's. At the same time, changes in demand, induced by both economic and sociological developments related to increasing per capita income, increasing social mobility, and urbanization, opened opportunities to escape competitive pressures by securing, at least for a short period of time, some profitable business in response to some peculiar new taste.

Both the woolen and cotton industries reflected these trends; but the latter less so. Woolen goods were of greater potential variety and combination. The bulk of output in the cotton industry consisted of quite standard goods, but the share of output represented by style conscious printed cotton fabrics was growing and by 1870 accounted for a considerable portion of total output. ${ }^{2}$

There was no organized fashion market, no seasonal openings revealing dominant trends and guiding the production lines of many mills into the same direction. There was, however, a general willingness on the part of buyers to buy something new and eagerness on the part of manufacturers to remain ahead of competitors by meeting that desire with an almost uninterrupted flow of new designs.

In 1850, for example, the Cocheco Manufacturing Co. introduced new cotton-print styles throughout the year regardless of the seasonal concentration of sales: two new styles in September; six in July; and more than six in all other months with a high of thirteen in October. ${ }^{3}$ At the end of our period, cotton-print seller Amory A. Lawrence, of Lawrence \& Co., observed, "to be successful we must be on the alert all the time and constantly making new brands and kind; the old $64 \times 64$ print seems to be about as dead a piece of merchandise now as there is: had we not gotten largely off into other things I do not know where our mills would have been." 4

3 Arthur H. Cole, The American Wool Manufacture (2 vols., Cambridge, Mass., 1926), I, 297-98. The total yardage of cotton cloth produced in the U.S. according to the Census of 1870 was $1,064,000,000$, table cloth not included, the yardage of cotton prints and delaines was $482,000,000$. We include in the category of cotton fabrics requiring frequent adjustments in style and color 35,000,000 yds. of lawns and fine muslins and 39,000,000 yds. of ginghams and checks, so that our discussion applies to roughly one-half of cotton cloth sold to the trade. U.S. Bureau of the Census, Ninth Census of the United States, III, Statistics of the Wealth and Industry of the United States (Washington, D.C., 1872), 596, 597,621 .

${ }^{3}$ Invoices of prints sent by Cocheco Mfg. Co. to Mason \& Lawrence, 1850, Mason \& Lawrence Papers (Mason \& Lawrence, 1843-1859; Mason, Lawrence \& Co., 1859-1861; Lawrence \& Co., 1861 and thereafter, in Baker Library, Harvard Graduate School of Business Administration, Boston).

4 Amory A. Lawrence to Amos A. Lawrence, undated [c. 1886], A. A. Lawrence Papers. 
It is also clear that in those lines of production where a single producer contributed a substantial percentage of total output, the sales volume of each producer at a given price could fluctuate considerably (even in the absence of any changes in aggregate demand) according to the sum of all competitors' decisions on output quantities. Thus, the individual producer had to adjust his production program not only to fashion trends but also to changes in his individual sales opportunities caused by output decisions by his competitors.

The drygoods commission merchant was the key as he largely controlled the production programs of the mills. ${ }^{5}$ The manufacturer had to know how to produce. The commission house, according to a salesman who proved his knowledge, had to know "just what to tell [the mills] . . . to make and what there is sure to be a demand for." 6

Of course, the role of the marketing agency in developing the production program of the mill varied from case to case. It ranged from mere approval or rejection to creative leadership. Bagnall reports cases at the two extremes of behavior. ${ }^{7}$ In the first instance, the mill took the initiative for product innovation. Damon, a small woolen manufacturer in Concord, Massachusetts, was advised by his marketing agency to produce satinet, a fabric made of cotton warp and woolen filling. When the business became unprofitable, Damon himself decided to put part of his machinery on woolen flannels; again without much success. In both fields he met strong competition. He then combined properties of each of his fabrics and brought out something completely new: a cotton-wool fabric with a flannel finish, the Domet Flannel. Damon's marketing agency merely examined the result, anticipated its success, encouraged its production, and introduced it to the trade.

In the second case, the marketing agency took the lead. The manufacturer was ready to enter flannel production but his commission house was already selling flannels produced by a competing

\footnotetext{
5 Caroline F. Ware, The Early New England Cotton Manufacture: A Study in Industrial Beginnings (Boston, 1931), 184; Fred M. Jones, “The Development of Marketing Channels in the United States to 1920," in Richard M. Clewett (ed.), Marketing Channels for Manufactured Products (Homewood, Ill., 1954), 26; Evelyn H. Knowlton, Pepperell's Progress: History of a Cotton Textile Company, 1844-1945 (Cambridge, Mass., 1948), 81, 82; Joseph Berger (ed.), Memoirs of a Corporation: The Story of Mary and Mack and Pacific Mills (Boston, 1950), 16.

' Henry A. Page to Moses T. Stevens, Nov. 25, 1870, Stevens Papers (business records of the woolen mills of Nathaniel Stevens, North Andover, 1786-1865, and his successors, in the Merrimack Valley Textile Museum, North Andover, Mass.).

${ }^{z}$ William R. Bagnall, "Sketches of Manufacturing Establishments in New York City and of Textile Establishments in the Eastern States," edited by Victor S. Clark (unpublished materials, 4 vols., 1908, in Baker Library, Harvard Graduate School of Business Administration, Boston), II, 1098-1101, 1170-71.
} 
mill. To avoid a market clash between his clients, the agent suggested a slight modification in the newcomer's fabric (an increase in the number of picks to the inch). The manufacturer took the advice and the new fabric sold well - notably under the marketing agency's name (as true creator of the new fabric) and not under the mill's brand. Whether or not the new fabric was actually created by the marketing agency, the decision to produce depended upon its advice, because only the marketing agency was in touch with the trade and in a position to judge prospective sales opportunities.

\section{The Hypothesis to Be Tested}

If the success of a product could thus depend largely on the judgment of the marketing agency, then the agency was entitled to share in the benefits of success. This share should show up in the price which a mill was willing to pay for advice on the choice of fabrics and, indirectly, in the compensation the marketing agency received for the whole bundle of services which it performed. Were it possible to isolate the price of the advisory service, we would gain one pecuniary measure for evaluating the choice of fabrics as a variable in the success of textile firms during our period. We would also gain further insight into the importance of those structural elements in the textile industry which are related to choices of fabric. We should not expect to arrive at an exact figure for the price of the fabric-advisory service; rather, we intend to show that its magnitude was considerable.

Isolation of the price of the fabric-advisory service requires several steps. First, we must separate from the other costs and profits of the commission house those we will call the normal costs. To this end, we shall use Lawrence \& Co. of Boston as our commissionhouse example. These normal costs are meant to cover only those spendings on human skills which were incurred by all commission houses in providing three basic services common to them all. These basic services include: first, the selling service proper, that is, bringing the seller into contact with buyers and soliciting sales; second, the bookkeeping service, that is, keeping track of all sales and monetary transactions; and third, the transportation service, that is, organizing and supervising the transit of goods from the mill to the wholesale markets.

We will find that for large agencies, the normal costs of these basic services were small compared with other costs and profits. And, since these large firms handled the bulk of total business, normal 
costs can thus be assumed to be small in the average; that is, small for all commission houses as a group. It will also be suggested that the performance of the basic services was not likely to yield considerable rents or profits to the commission house.

In a second step, we shall look at the additional services performed by most of the commission houses and at both the costs incurred and the rents and profits realized in their performance. Specifically, we shall consider: credit service, that is, the security against losses provided to the mill through the commission house's expert knowledge of the credit standing of buyers; financial service; and finally, the fabric-advisory service.

We shall find that these additional services could introduce a monopolistic element into the marketing mechanism: by offering a package of additional services different from that of a competitor, a commission house could attach a mill to itself and influence the mill's demand for its services, pushing up the price of this package and/or gaining additional business. Even if the price were very inflexible, the commission house could at least realize a benefit from economies of scale involved in decreasing its average normal costs.

A mill's spendings on additional services, that is, its payments above normal costs, could reflect any or all of three elements: first, an outlay on a factor of production representing a change in the basic services, for example, on a salaried employee with special skills or on a partner working in a particular capacity; second, additional elements of profit because of a marketing agency's ability to exploit a factor of production or its temporary leading position in the performance of a special service or mixture of services; third, an element of rent accruing to an agent whose package of services was no better than most but who provided his services at less cost than could his average competitor.

We shall try to estimate the value each of these three elements had for each of the distinguiishable additional services - an estimation which involves more judgment than measurement. These values changed over time, because rent and profit elements changed, or because the competitive price of a factor of production changed, or because the need of a service changed. The package of additional services most likely to attract a mill and to bind it to the commission house was not the same in 1850 as it was in 1880 . The fabricadvisory service, however, gained in relative importance throughout the period.

In a third step, we shall again make use of the accounting data of Lawrence \& Co. in order to get more directly at the value of this 
crucial fabric-advisory service. This case study yields a figure for the price one had to pay in the market for the special skills involved in giving such advice.

Before entering upon this three-step argument, however, we must resolve a preliminary problem: payments by a mill to its marketing agency would not reflect the true value of the package of basic and additional services provided by the agency if either controlled the other through financial ties, collusive arrangements, or other factors barring a free bargaining process.

\section{Was the Market for Services Competttive?}

Our argument depends upon the assumptions that the drygoods commission houses offered their services in a competitive market and that the mills purchased these services under competitive conditions as well. The first assumption may be questioned; the second appears to rest on safer ground, as follows.

A large number of textile mills was selling in a few wholesale centers; for example, 304 woolen and 250 cotton producers in Maine, New Hampshire, and Massachusetts alone were competing for the services of commission houses by 1870.8 In spite of the collusive disposition of the industry, actual agreement on selling terms was apparently never reached between producers and marketers as groups. ${ }^{9}$ Cases of mills controlling commission houses by ownership were also exceptional. ${ }^{10}$

The number of competing marketers was also high -74 houses in Boston alone by $1870 .{ }^{11}$ There is fragmentary evidence of a competitive spirit among established houses: Mason \& Lawrence,

\footnotetext{
Ninth Census of the United States, III, Statistics of the Wealth and Industry of the United States, passim.

${ }^{2}$ Collective bargaining took place between the commission house A. \& A. Lawrence \& Co. and its mills when the latter in 1852 took steps for common action by twenty-eight manufacturing companies to prevent A. \& A. Lawrence from raising the rate of commissions. The result of this attempt at mobilizing some countervailing power against the leading commission house was a compromise between $A$. \& A. Lawrence \& Co. and the mills for which it sold, but another commission house, Francis Skinner \& Co., felt free to change its terms at the same time without being bound by the Lawrence compromise. Knowlton, Pepperell's Progress, 77-79.

${ }_{10}$ There were some early cases of direct selling. The partnership B. B. \& R. Knight, Providence, formed in 1852, managed by two brothers, one a merchant, the other a manufacturer, handled both production at its mills and marketing of the product to the trade; there are other cases of this brotherly backward or forward integration. Bagnall, "Sketches of Manufacturing Establishments," II, 1402-1431.

11 The number of seventy-four drygoods commission houses in Boston by 1870 includes those firms which, according to Dockham's U. S. Cotton, Woolen, Silk, and Linen Manufacturers' Report and Directory, 1870-71 (Boston, 1870), were actually selling for textile mills, i.e., not only those listed as commission merchants but also those appearing under the title of a manufacturing firm as its selling agent, provided that they are reported on by R. G. Dun \& Co. for doing primarily a drygoods commission business. R. G. Dun \& Co., credit reporting ledgers for Boston (Baker Library, Harvard Graduate School of Business Administration, Boston).
} 
for example, was ready to undersell competitors by 1843 ; Henry A. Page of Faulkner, Page \& Co. tried to change a mill's allegiance by 1877.12 More important, however, newcomers' competition was always effective: competition from importers turning to a domestic business or from retailers or jobbers changing over to a commission business or combining the latter with wholesaling or retailing. ${ }^{13}$

The rise of new drygoods centers also offered alternatives to existing channels. ${ }^{14}$ Thus, concentration of business in the hands of the leading houses was not particularly impressive: the mills for which the eighteen leading Boston commission houses sold by 1870 represented 59 per cent of the total capital invested in the woolen and cotton industries of Maine, New Hampshire, and Massachusetts. ${ }^{15}$ It does not appear, therefore, that the mills as a group were tied to any exclusive group of commission houses. Yet mills may have been (and partly were) individually controlled by their commission houses through ownership.

Mercantile interests continued to be important in textile-mill ownership throughout the nineteenth century. ${ }^{16}$ But did commission houses generally own the mills for which they sold? A comparison of the total amount of funds available to the Boston commission houses for investment with the capital invested in the mills they served reveals that the commission houses could hardly have purchased a controlling interest in a majority of the mills, much less actually have owned them.

Our estimation of total capital available to the commission houses for investment is based on figures for the total "worth" of seventy-four Boston houses as given in the credit-rating reports of R. G. Dun \& Co. for 1870. It is granted that estimation of this "worth," that is, the total amount of capital at the risk of business plus capital actually invested in the mercantile firm and the property of the partners in whatever way it happened to be invested,

\footnotetext{
${ }_{12}$ Robert M. Mason to Amos A. Lawrence, March 9, 1843, A. A. Lawrence Papers; Henry A. Page to Moses T. Stevens, April 12, 1877, Stevens Papers.

13 Of 74 drygoods commission merchants doing business in Boston by 1870, 2 had started out as jobbers, 3 as importers, 4 had combined jobbing and importing before tuming to a domestic commission business, 10 did a mixed business in 1870 . R. G. Dun \& Co., credit reporting ledgers for Boston.

${ }_{14}$ Fred M. Jones, Middlemen in the Domestic Trade of the United States, 1800-1860 (Urbana, Ill., 1937), 15.

${ }_{15}$ The result is a lower limit for the actual figure. The amount of capital invested in the mills for which each commission house sold has been calculated on the basis of capital figures given for incorporated companies in Dockham's U. S. Textile Directory, 1870-71. We are assuming that the capital reported by the ninth Census for the cotton and woolen industries of Maine, New Hampshire, and Massachusetts approximates the capital actually invested in all mills selling through Boston houses, in other words, that the capital represented by those mills in those three states not selling through Boston commission houses is about equal to the capital of mills from other states selling through Boston houses.

16 Melvin T, Copeland, The Cotton Manufacturing Industry of the United States (Cambridge, Mass., 1912), 215.
} 
would have been difficult even on the basis of complete inside information - which the credit-rating agency did not have. The latter's figures were based largely on interviews, correspondence, and guesswork. We take them only for a rough approximation of the order of size. ${ }^{17}$

Dun's figures indicate a total commission-house "worth" of $\$ 31,000,000$. The capital requirements of a commission business proper were small and this left the bulk of the total "worth" of a commission house to be disposed of at will; for example, to be invested in manufacturing property. We estimate (disregarding for a moment the actual investment policies of the commission houses) that roughly $\$ 30,000,000$ of the $\$ 31,000,000$ "worth" could have been available for the purchase of a controlling interest in the mills for which the commission houses sold. This amount compares with the $\$ 97,000,000$ capitalization attributed to all woolen and cotton mills in Maine, New Hampshire, and Massachusetts (the mills predominantly selling through Boston) by the U. S. Census of 1870 .

Thus, we suggest that the Boston commission houses had the potential to acquire a majority equity in somewhat less than 60 per cent of the mills for which they sold. There is no reason, of course, to believe that the commission houses actually locked up all their disposable funds in the mills. We know that the capital of some commission-house partners was invested in a broad variety of property: Amos A. Lawrence, for example, held factory stock at a market value of $\$ 166,700$ in 1857 as well as $\$ 114,500$ worth of real estate; the senior partner of George C. Richardson \& Co. was said to be a large real estate owner; Joseph Nickerson \& Co. made money in railroad stock by $1878 .{ }^{18}$

Some of the commission houses were both marketers and bankers. ${ }^{19}$ Many enjoyed considerable liquidity and were able to make loans to the mills. The more important advances from the commission house to the mill came to be, the less likely was it for commission houses to have their funds invested in mill stock. ${ }^{20}$ On

\footnotetext{
${ }^{17}$ R. G. Dun \& Co, credit reporting ledgers for Boston. For a polemic analysis of the creditability of the agency's figures see Thomas F. Meagher, The Commercial Agency "System" of the United States and Canada Exposed (New York, 1876).

${ }_{18}$ Property of Amos A. Lawrence, 1857, A. A. Lawrence Papers; R. G. Dun \& Co., credit reporting ledgers for Boston, vol. 4, p. 334 (vol. 73 of Massachusetts series), February 26, 1879 (short citation used hereafter: Dun \& Co., Boston: 4.334(73), 2-26-79; Dun \& Co., Boston: 2.886(70), 11-20-78.

${ }_{19}$ Dun \& Co., Boston: 1.103(67), 4-19-56 (Mudge, Sawyer \& Co.); 2.495(69), 11-3057 (Nevins \& Co.).

${ }_{20}$ William H. Hilliger, James Talcott: Merchant and his Time (New York, 1937), Ewing and Norton, Broadlooms, 28, 54, 76, 78, 80, 94. Copeland, Cotton Manufacturing, 210, 212, 215.
} 
TABLE 1

Average Monthly Payments of the Cocheco Manufacturing Co. To LaWrence \& Co. on Commissions and Salaries OF EMPLOYEES, 1849-1883

\begin{tabular}{|c|c|c|c|c|c|c|c|c|c|c|}
\hline Year & $\underset{(\$)}{A}$ & $\underset{(A \% G)}{B}$ & $\begin{array}{c}\mathrm{C} \\
(\$)\end{array}$ & $\underset{(\$)}{D}$ & $\begin{array}{c}E \\
(C+D)\end{array}$ & $\frac{F}{(E \% G)}$ & $\begin{array}{c}\mathbf{G} \\
(\mathrm{A}+\mathrm{E})\end{array}$ & $\underset{(\$ 1,000)}{\mathrm{H}}$ & $\underset{(E \% H}{I}$ & $\underset{G \% \mathrm{H})}{\mathbf{J}}$ \\
\hline 1849 & 1,154 & 84 & 132 & 89 & 221 & 16 & 1,375 & 76 & 0.29 & 1.81 \\
\hline 1850 & 1,026 & 86 & 84 & 81 & 165 & 14 & 1,191 & 72 & 0.23 & 1.67 \\
\hline 1851 & 1,024 & 81 & 140 & 95 & 235 & 19 & 1,259 & 65 & 0.36 & 1.94 \\
\hline 1852 & 1,355 & 82 & 210 & 87 & 297 & 18 & 1,652 & 85 & 0.35 & 1.95 \\
\hline 1853 & 1,358 & 78 & 269 & 108 & 377 & 22 & 1,735 & 89 & 0.42 & 1.95 \\
\hline 1854 & 1,236 & 77 & 216 & 156 & 372 & 23 & 1,608 & 77 & 0.48 & 2.08 \\
\hline 1855 & 1,353 & 77 & 231 & 181 & 412 & 23 & 1,765 & 85 & 0.49 & 2.09 \\
\hline 1856 & 1,239 & 75 & 201 & 207 & 408 & 25 & 1,647 & 83 & 0.49 & 1.99 \\
\hline 1857 & 929 & 72 & 162 & 192 & 354 & 28 & 1,283 & 61 & 0.58 & 2.09 \\
\hline 1858 & 1,335 & 78 & 244 & 133 & 377 & 22 & 1,712 & 91 & 0.41 & 1.88 \\
\hline 1859 & 1,010 & 76 & 222 & 102 & 324 & 24 & 1,334 & 81 & 0.40 & 1.66 \\
\hline 1860 & 967 & 73 & 257 & 94 & 351 & 27 & 1,318 & 77 & 0.45 & 1.71 \\
\hline 1861 & 626 & 64 & 242 & 106 & 348 & 36 & 974 & 50 & 0.70 & 1.95 \\
\hline 1862 & 711 & 72 & 196 & 86 & 282 & 28 & 993 & 57 & 0.50 & 1.75 \\
\hline 1863 & 399 & 60 & 184 & 86 & 270 & 40 & 669 & 32 & 0.85 & 2.10 \\
\hline 1864 & 1,470 & 83 & 194 & 110 & 304 & 17 & 1,774 & 118 & 0.26 & 1.51 \\
\hline 1865 & 1,535 & 81 & 222 & 149 & 371 & 19 & 1,906 & 123 & 0.30 & 1.55 \\
\hline 1866 & 2,360 & 86 & 228 & 161 & 389 & 14 & 2,749 & 189 & 0.21 & 1.45 \\
\hline 1867 & 2,470 & 86 & 201 & 188 & 389 & 14 & 2,859 & 198 & 0.20 & 1.44 \\
\hline 1868 & 2,060 & 83 & 182 & 231 & 413 & 17 & 2,473 & 165 & 0.25 & 1.50 \\
\hline 1869 & 2,180 & 84 & 164 & 23 & 399 & 16 & 2,579 & 174 & 0.23 & 1.48 \\
\hline 1870 & 2,840 & 87 & 155 & 259 & 414 & 13 & 3,254 & 190 & 0.22 & 1.71 \\
\hline 1871 & 3,660 & 90 & 134 & 255 & 389 & 10 & 4,049 & 209 & 0.19 & 1.94 \\
\hline 1872 & 4,230 & 92 & 142 & 231 & 373 & 8 & 4,603 & 244 & 0.15 & 1.88 \\
\hline 1873 & 4,720 & 92 & 188 & 203 & 391 & 8 & 5,111 & 271 & 0.14 & 1.88 \\
\hline 1874 & 4,370 & 91 & 225 & 186 & 411 & 9 & 4,781 & 250 & 0.16 & 1.91 \\
\hline 1875 & 3,940 & 89 & 225 & 282 & 507 & 11 & 4,447 & 225 & 0.23 & 1.98 \\
\hline 1876 & 3,615 & 88 & 192 & 324 & 516 & 12 & 4,131 & 206 & 0.25 & 2.00 \\
\hline 1877 & 3,305 & 87 & 167 & 308 & 475 & 13 & 3,780 & 189 & 0.25 & 2.00 \\
\hline 1878 & 2,620 & 83 & 150 & 388 & 538 & 17 & 3,158 & 150 & 0.36 & 2.10 \\
\hline 1879 & 3,375 & 86 & 150 & -411 & 561 & 14 & 3,936 & 194 & 0.29 & 2.02 \\
\hline 1880 & 4,150 & 87 & 167 & 458 & 625 & 13 & 4,775 & 237 & 0.26 & 2.02 \\
\hline 1881 & 3,480 & 90 & - & 392 & 392 & 10 & 3,872 & 199 & $(0.20)$ & 1.95 \\
\hline 1882 & 3,480 & 91 & - & 355 & 355 & 9 & 3,835 & 200 & $(0.18)$ & 1.92 \\
\hline 1883 & 3,425 & 94 & - & 235 & 235 & 6 & 3,660 & 196 & $(0.12)$ & 1.87 \\
\hline
\end{tabular}

A. Average monthly regular commissions going to partners of Lawrence \& Co.

C. Average monthly commissions going to sub-agent in New York (after May 31, 1859, part of salary of employee in New York).

of salary of employee in New York).

D. Average monthly share of Cocheco Manufacturing Co. in salaries paid to employees by Lawrence \& $\mathrm{Co}$. in addition to $\mathrm{C}$.

H. Average monthly gross wholesale value of sales.

For additional notes see Appendix. 
the whole, then, we argue that the number of mills free from control by commission-house ownership was sufficient for the services of the commission houses to have a competitive market price. This leaves open the possibility of cases, of course, in which, on the basis of control through ownership, selling terms may have deviated from a competitive level.

\section{The Value of Basic Services}

Table 1 gives a series of prices for the basic services provided by Mason \& Lawrence (later Lawrence \& Co.) in selling the products of the Cocheco Manufacturing Co., a cotton-print mill, from 1849 to 1883 . Column I represents the ratio between the mill's payments for the selling service (column $\mathrm{E}$ ) and the wholesale value of the product handled by the commission house (column $\mathbf{H}$ ). The figures give a monthly average for each commercial year.

Payments by the mill for the selling service included two components. First, they include part of the amount which the mill contributed to the general expenses of the commission house - payments on salaries, store rent, taxes, stationery, and so on. The proportion of total general expenses represented by salaries was stable: 53 per cent on the average for the two years $1849-1850 ; 47$ per cent, 1859-1860 and 1869-1870; and 56 per cent, 1879-1880. ${ }^{21}$ We have used these proportions in calculating the increment of general expenses represented by salaries of employees (column D). Second, the selling service payments contain commissions paid by the mill to a sub-agent or, after May 31,1859 , to an employee of the commission house, who was stationed in New York (column C).

We propose to combine the series of payments to salaried employees (D) and the series of payments to sub-agents (C) into a series representing the cost of the selling service as a whole (column E). We assume that this service was performed by these employees and sub-agents with no one else adding much to its performance.

Is this a valid assumption? How was it in reality? We are well informed on the activities of Lawrence \& Co.'s sub-agents through their correspondence with the Boston office during the year 1850 . Where our information is not sufficient as far as the New York subagent, R. H. Snow, is concerned, we can make use of the evidence available for his Philadelphia colleague, W. E. Pratt, who worked in the same capacity.

${ }^{21}$ Calculated on the basis of entries in the ledgers and waste books of Mason \& Lawrence and Lawrence \& Co. respectively, Mason \& Lawrence Papers. 
The sub-agents did provide the selling service in their respective markets. Nobody was there to assist them directly in the promotion of sales. In addition, they helped the home office perform other than basic services. They informed Mason \& Lawrence on price trends, quoting competing offers, reported on the sales success of competitors, and thus assisted the Boston office in making price decisions for distant markets. ${ }^{22}$ They gave their judgment on trends in the development of aggregate demand or on changes in buyers' preferences for particular fabrics ${ }^{23}$ and on their taste for particular colors or designs. ${ }^{24}$ The Philadelphia sub-agent was personally involved on a few occasions in getting up new styles in prints and he decided on one occasion on the proportion in which different colors were to be printed. ${ }^{25}$ Thus, sub-agents helped the commission house to reach decisions on the choice of fabrics. They also investigated the credit standing of buyers, soliciting information on which Mason \& Lawrence would be able to base their conclusions. ${ }^{26}$ This leaves us with the impression that the sub-agents' earnings (column C) fully covered the value of their salesmanship and may have included an undeterminable value of awareness of a market situation and of future trends and a knowledge of the credit standing of buyers.

What the mill paid on salaried employees (column D) was not related to neatly defined jobs and does not represent a price for a particular service. Instead of asking what activities it could have covered, we ask to what extent it would have covered the costs of selling the goods not sold by sub-agents outside of Boston? The gross wholesale value of sales effected through the Boston office amounted to 71 per cent of the corresponding value of sales effected in New York by the sub-agent during the years 1850-1855. ${ }^{27}$ Payments to salaried employees in Boston for these years were 62 per cent of commissions paid to the New York sub-agent. Would an amount equal to 62 per cent of the New York sub-agent's commis-

2 R. H. Snow to Mason \& Lawrence, July 19, 24, 25, 26, August 7, 8, September 10, 13, October 5, 9, 30, 1850, W. E. Pratt to Mason \& Lawrence, January 11, February 17, April 4, July 3, October 17, 1850, Mason \& Lawrence Papers.

${ }^{23}$ Snow to Mason \& Lawrence, September 13, 1850, Pratt to Mason \& Lawrence, January $5,15,22,31$, February 19, March 16, 18, April 11, October 1, November 4, 1850, Mason \& Lawrence Papers.

${ }^{24}$ Snow to Mason \& Lawrence, October 5, 1850, Pratt to Mason \& Lawrence, January 18, 23, February 6, 7, 8, 11, March 20, April 8, July 7, 26, September 2, December 26, 1850 , ibid.

${ }_{25}$ Pratt to Mason \& Lawrence, February 18, 25, March 7, 26, April 1, 1850, ibid.

${ }_{28}^{2}$ Ibid., January 12, 21, February 26, 1850.

27 Ibid., waste books, series on monthly wholesale value of total sales and of sales effected in New York; series of commissions paid to the commission house for all sales effected outside of Boston at a given rate of commission of $1 / 2$ per cent. From this series I have calculated the wholesale value of sales effected outside of Boston, the difference between total sales and sales made outside Boston, and finally the ratio between Boston sales and New York sales. 
sion have paid for 71 per cent of his New York sales volume if these sales had been made in Boston instead of New York? Average selling costs should fall as sales volume grows, but it was easier to sell the 71 per cent in Boston's narrow market than it was to sell the 100 per cent in New York's wider market. Boston must have been a more comfortable place for making sales at that time than New York. It took quite a salesman to cover the rapidly changing New York market, whereas long established contacts in Boston made selling easier. ${ }^{28}$

It appears safe to say, then, that the amount of payments made to salaried employees approximated the price of the selling service as far as provided by the Boston office. Since commissions paid to sub-agents covered a little bit more than just the selling service in New York, total payments to sub-agents (column C) and to salaried employees (column D) approximated rather closely the price for the total selling service (column E).

Bookkeeping, the second of the basic services, was cheap. By the middle of the century a bookkeeper earned a monthly salary of $\$ 65 .{ }^{29}$ Only one-third of this salary fell to the Cocheco Manufacturing Co., less than 10 per cent of the price of the selling service proper. $^{30}$ As to the provision of transportation service from the mill to the wholesale markets, it was also cheap as long as it could be left in the hands of a clerk with a salary in the neighborhood of that of a bookkeeper. Certainly, transportation problems did not rank among the crucial ones a commission house had to face. Amory Lawrence, son of the senior partner of Lawrence \& Co., used to write his father lengthy reports on business matters without ever mentioning transportation. But he was personally involved, as a junior partner, even with the "freight details" until an effort was made to relieve him from his task to which, it was said, "he was given a good deal of attention of late at a greater expense of time and money than he probably realizes." 31

We are here quoting a clerk's letter to the senior; a clerk wanted to make sure that at least the boss "realized" what a burden he was about to take over. We learn from the statement that the clerks could handle freight problems by themselves if the firm so desired. It was the clerks who wrote and signed letters on trans-

${ }^{28}$ As shown by the experiences of James Talcott. Hilliger, Talcott, passim.

Joseph B. Wheelock to Amos A. Lawrence, April 7, 1845, A. A. Lawrence Papers; Elva Tooker, Nathan Trotter: Philadelphia Merchant, 1787-1853 (Cambridge, Mass., 1955), 63.

s0 The Cocheco Co. paid 33.8 per cent of the general expenses of the commission house Mason \& Lawrence from December 1, 1848 to November 30, 1851, Mason \& Lawrence Papers, ledgers $B$ and $C$.

34 J. F. Dorsey to Amos A. Lawrence, Jan. 28, 1886, A. A. Lawrence Papers. 
portation questions from Faulkner, Page \& Co. to N. Stevens \& Sons. ${ }^{32}$ Another 10 per cent of the price of the selling service would thus amply cover the third of the basic services. We do not think that elements of exploitation were very significant and that the true value of the basic services should thus be looked for in the profits of the partners.

Table 1, column F compares payments to sub-agents and to salaried employees (column E), which we have equated to the total price of the selling service, with total payments by the mill for the whole package of services provided by the commission house (column G). Payments to sub-agents and salaried employees were never higher than 28 per cent of total payments up to the Civil War. We shall refer to a possible change over time below. If the combined price of the bookkeeping and transportation services was, as suggested, not more than one-fifth of the price of the selling service, the basic services provided by the commission house accounted for only one-third of the amount of total payments from mill to marketing agency. The other two-thirds, probably accruing to the partners, remain to be explained.

\section{The Value of Additional Services}

There were three additional services provided by the commission house to the mill whose impact on the costs, rents, and profits of the commission house we shall now estimate: (1) giving some security against credit losses of the mill through expert knowledge on the credit standing of buyers (the credit service); (2) bringing about financial aid (the financial service); and (3) giving advice on the choice of fabrics (the fabric-advisory service).

A good record of doing business safely, thanks to sound credit judgment, was certainly important for the success of a commission house. Although good credit service was a prerequisite for getting any business at all, it is difficult to believe that, for our particular type of business, it was a very distinguishing factor, one which bound the mills to particular commission houses making for extra profits, since good judgment was common to many houses. A dry goods commission house dealt with a relatively small number of buyers. Francis Skinner \& Co. sold the product of the Pepperell Manufacturing Co. to only 240 domestic customers from July 1851 to June $1852 .{ }^{33}$ Since the continued patronage of a mill partly deas Faulkner, Kimball \& Co. (until July 1, 1871, then Faulkner, Page \& Co.) to N. Stevens \& Co., 1867-1880, passim, Stevens Papers.

33 Knowlton, Pepperell's Progress, 83. 
pended on it, a marketing agency specialized in dealing with these buyers and was likely to become intimately involved with each of them over time. Ability of buyers to pay in the past was good evidence for their reliability in the near future. This evidence was available to all houses of some experience, and there were many such: thirty-seven out of seventy-four doing business in Boston by 1870 had been in business since at least $1850 .^{34}$ Evidence of safe credit standing going beyond a record of past achievements was difficult to come by for anybody.

If credit service experience was crucial, newcomers must have found it costly to come up to the common standard. Amos A. Lawrence, upon entering business on his own in 1836, "travelled into all the U. S. states with 2 business friends to examine credits." 35 Such newcomers' costs granted established houses a rent. It is at this point where the credit-rating agencies were likely to have their significance; institutions providing some information on credit standings increased following the establishment of Lewis Tappan's Mercantile Agency in $1841 .^{36}$ Although the degree of accuracy of the ratings of these agencies is questionable, they were at least able to tell their subscribers how long a potential buyer had been in business without failure and to report changes in the personnel of a firm; that is, they were able to convey a good part of the very substance of an old firm's experience - knowledge of reliability of buyers in the past - to anybody willing to pay their subscription fee. Newcomers' costs of providing credit service must have approximated the price of agency information; rents accruing to established houses must have been excluded. And this price was relatively small: originally $\$ 50$ a year to firms with a trade volume above $\$ 50,000$ a year and $\$ 300$ to those with a volume of more than $\$ 500,000$.

We do not believe, therefore, that credit information weighed heavily in the price of a commission firm's services at the beginning of our period, much less toward the end. The importance of credit information decreased with the length of the credit period and, hence, so did its price. ${ }^{37}$ Knowlton gives as the usual credit periods

\footnotetext{
s4 R. G. Dun \& Co., credit reporting ledgers for Boston. Continuity in the history of a commission house has been assumed if the style of its name remained unchanged, if the senior partner did not change, if in case of retirement of the senior partner the former junior partners continued to do business together.

35 Miscellaneous letters, $1853-1887$ and biographical notes on Amos A. Lawrence, A. A. Lawrence Papers.

${ }^{36}$ For a sketch of the development of credit rating agencies see: Dun \& Bradstreet, Inc., The Centennial of the Birth of Impartial Credit Reporting: An American Idea (New York, 1941).

${ }^{37}$ Other things being equal. Credit risks may have increased with the territorial growth
} 
granted by Francis Skinner \& Co. in selling cotton fabrics in different years: eight months by 1855; after the panic of 1857 cash, four, six, or eight months; six months by 1859; and thirty days during and after the Civil War throughout our period. ${ }^{38}$ Faulkner, Kimball \& Co. sold its woolens by 1870 on credit terms of thirty days for the most part also. Out of a sample of 183 sales effected in Boston and New York from January 1 to October 30, 1870, 7 per cent were sold on credit terms of ten days, 56 per cent on thirty days, 26 percent on sixty days, and 11 per cent on four months. ${ }^{39}$ Shorter credit terms reduced the danger of unforeseeable developments in the financial standing of a buyer.

A huge share in the price of the package of services provided by a drygoods commission house still remains to be explained. We think that at the beginning of our period the second additional service, bringing about financial aid, could account for more than half of the residual in some cases but for much less in the late 1870 's. Cost factors - the price of the brokerage service involved in financial aid - were negligible because there was no need for contacting borrowers and the lenders were few and close at hand. But financial service was, as long as only a limited number of commission houses was able to provide it, important for two reasons. It attracted business and, therefore, could increase profits on the total package of services performed. It also yielded a substantial rent.

By the middle of the century it was still true that "the chief credit was with the selling house," not with the mill. ${ }^{40}$ The commission house was a better risk for outsiders than was the mill. By interposing its own credit standing, the commission house was able to raise money cheaper than the mill was able to do. Since the commission house was so close to the financial operations of the mill, it did not incur the risks of an outsider. If, therefore, the mill paid the commission house the same rate of interest the former would have had to pay to a note broker, then the commission house earned a premium, a "profit on interest," proportional to the difference between the credit standing of the mill (worse) and the credit standing of commission house (better) in the market. If the mill had only to pay the commission house what the latter paid in

\footnotetext{
of the market; is it not reasonable to expect that this increase was offset by the development of the communication system?

${ }^{38}$ Knowlton, Pepperell's Progress, $90 \mathrm{f}$.

3 Faulkmer, Kimball \& Co. to N. Stevens \& Co., Stevens Papers. For shortening of credit periods in general, see Albert $O$. Greef, The Commercial Paper House in the United States (Cambridge, Mass., 1938), 70.

to Copeland, Cotton Manufacturing, 197.
} 
the market, it was the mill who at first sight received a benefit. This was the case if the commission house endorsed the mill's notes, thus enabling the mill to discount the notes at a bank at the same rate the commission house would have been granted. For this benefit the mill may have recompensated the commission house in part through higher commissions as long as competition among commission houses did not squeeze out such a recompensation. Here we speak of an "interest element in commissions."

"Profit on interest" is empirically feasible. Mason \& Lawrence received 6 per cent interest for discounting the Cocheco Manufacturing Co.'s notes, a rate unchanged even in October and November 1857; clearly it was fixed at the level of the legal maximum. The same rate appears later for other types of loans. From June 1, 1844 to November 30,1852, Mason \& Lawrence paid interest on $\$ 70,168$ employed in its business or invested in the mills on short terms; in the same period they received interest payments on their investments of $\$ 90,319$. Even without taking into account that some funds were held in non-interest-bearing employments, e.g., as cash, the ratio between the interest rates paid and received was 78:100. If Mason \& Lawrence got 6 per cent from the mills, it paid not more than 4.7 per cent to their creditors - a figure which approximates a market rate. A very low proportion of the total interest payments to commission-house creditors went to the partners; most of them, 83 per cent in the period from December 1,1850 to May 31, 1851, went to banks, insurance companies, or other money lenders. ${ }^{41}$

In contrast, the "interest element in commissions" can only be inferred from differences in interest rates paid by mills of a given credit standing, either to a commission house or to outsiders, and under the assumption that some proportion of the mill's benefit went to the commission house. Given the fact that commission houses apparently charged the maximum legal interest rate, and given the high interest rates in the streets for second-class paper, substantial "interest elements in commissions" are at least very plausible. ${ }^{42}$

But in the 1870's "interest elements in commissions" were likely to decrease for three reasons: the mills required less money; they had improved their credit standing; and the commission houses, in an easy money market, were competing for investment opportunities. We referred to the fact that credit periods became shorter

\footnotetext{
1 Cash books $\mathrm{B}$ and $\mathrm{C}$, passim, waste book B, May 31,1870 (interest of 6 per cent on unspecified loan), ledger C (interest account)., Mason \& Lawrence Papers. No individual rates for interest paid to creditors appear on the books.

${ }^{42}$ Joseph G. Martin, Martin's Boston Stock Market: Eighty-Eight Years (Boston, 1886), "Monthly Reports on Money Market," $44 \mathrm{ff}$.
} 
TABLe 2

Discounts on Commercial Paper

Pam by Boston Commission Houses and A Textile

Manufacturing Firm, 1875-1879

\begin{tabular}{|c|c|c|c|c|c|c|c|c|}
\hline \multirow[b]{2}{*}{ Firm } & \multicolumn{2}{|c|}{1875} & \multicolumn{2}{|c|}{1876} & \multicolumn{2}{|c|}{1877} & 1878 & 1879 \\
\hline & $\begin{array}{l}\text { Apr. } \\
\mathbf{2 6}\end{array}$ & $\begin{array}{l}\text { Nov. } \\
10\end{array}$ & $\underset{24}{\text { Apr. }}$ & $\begin{array}{c}\text { Nov. } \\
20\end{array}$ & $\begin{array}{l}\text { Apr. } \\
23\end{array}$ & $\underline{-}$ & $\begin{array}{ll}- & \text { Oct. } \\
- & 1\end{array}$ & $\begin{array}{c}\text { Feb. } \\
26\end{array}$ \\
\hline
\end{tabular}

Allen, Lane \& Co. 6 - - $64 \% / 5-\ldots$

Barnes, Ward \& Co. $7 \%$ \% $7 / 7 \%$ - - - - -

Dale Bros. \& Co. 7 - - - - -

Danforth, Clark \&

Co. $6 \%$ - - - - - -

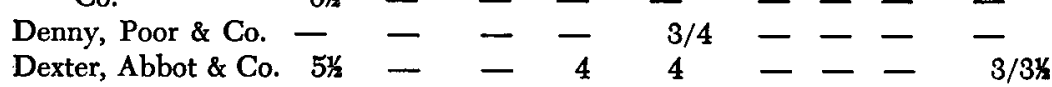

Faulkner, Page

$\begin{aligned} & \text { \& Co. } \\ & \text { Floyd Bros. \& Co. }\end{aligned}-$ -
-

Frost \& Co. $\quad-\quad-\quad$ - $4 \%$ 万

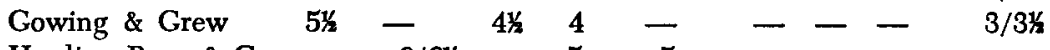

Harding Bros. \& Co. $-\quad 6 / 6 \%$ - 5 5 5 - - -

Harding, Colby \& Co. 5\% - - 4\% - - - -

Holbrook \& Co. $5 \quad 5 \%$ - 4 - $-4 / 4 \%$

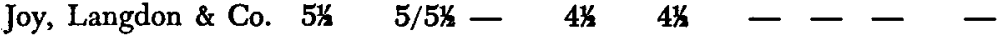

Kelly, Thomas \&

Co.

Leland, Allen \&

Bates

Mackintosh, Green

\& Co.
Minot, Hooper \& Co. $-\quad-$

$-\quad-12--\quad-10 / 12-$

Mudge, Sawyer \&

Co.

Perry, Wendell, Fay

$\&$ Co.

$5--3 \frac{1}{2} / 4--6-3$

Richardson \&

Whitney

Richardson \& Co.

Upham, Tucker \&

Co.

Wentworth \& Co.

Whittemore, Cabot \&

Co.

$6 \quad 6---$

$3 \% / 4$

Wright, Bliss \&

Fabyan

12 $5 / 5 \%$

$\overline{4}$

- -

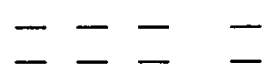

Lawrence Manufacturing
Co.
7
$4 \frac{1}{2} / 6 \quad 3 \% \quad 3 \frac{1}{2} \quad 4$
$4 / 4 \frac{1}{2} \quad 3 \frac{1}{2}$

For notes, see Appendix. 
over time, hence credit requirements of mills also decreased. Interest rates paid by mills and by commission houses to outsiders approached each other. R. G. Dun \& Co. gives at certain dates during the years 1875 to 1879 the discount rates usually paid by a number of Boston commission houses on their paper or on mill paper endorsed by them. ${ }^{43}$ Table 2 shows these rates and compares them with rates paid on unendorsed mill paper. ${ }^{44}$ We find that the latter ranged among those paid by the very best commission houses.

Much casual evidence for considerable liquidity of commission houses and readiness to assume financial responsibility is available: Mackintosh, Green \& Horton were said to have "what capital they can use to advantage;" Dexter, Abbot \& Co. had "ample means for handling" its accounts; Faulkner, Page \& Co. found it difficult to employ all its money. Several firms were reported by R. G. Dun \& Co. to buy paper apart from what they took from the mills. ${ }^{45}$ Where a large house carried more mills than it easily could supply with funds, it could tap outside resources. ${ }^{46}$ What it meant to have outside money available is illustrated by Amory A. Lawrence cautioning his father against accepting a banker's money: ${ }^{47}$

Don't think we are short of money and must have a large deposit from some one or a line of an outside bank (Beat's for example) for we are not, and if we should borrow, we had better use our own banks, as we shall want but for a few months, and we have not had a loan at any of them for a long time. If you should happen to whisper to Beat that you thought perhaps some time you might want some money he will bother you until you take of him.

Although uncertain as to what portion of the total price of all services the fabric-advisory service represented at the beginning of our period, we can now say that it accounted for a large portion in the 1870's unless either the total price of all services declined over time or the price of the basic services increased.

Casual observation of the movement of commission rates does not suggest a decrease. ${ }^{48}$ The rates of commission do not, however, say very much about the actual price paid for the services for two reasons. First, the commission payments were obviously less than total

${ }^{43}$ R. G. Dun \& Co., credit reporting ledgers for Boston.

4 "Rates paid by Lawrence Manufacturing Company according to entries in Notes and Bills payable, 1874-1908." This single bill book is among the Mason \& Lawrence Papers, vol. 112.

t5 Dun \& Co., Boston: 3.477(72), 1-3-76. (Mackintosh, Green \& Horton); 1.500 z/29(68), 9-7-83 (Dexter, Abbot \& Co.); 2.599 a/100(69), 9-26-79 (Faullner, Page \& Co.); 1.265(68) 11-1-77 (Parker, Wilder \& Co.); 15.495(84) 11-1-77 (Wendell, Hutchinson \& Co.); 4.352 (73), 11-20-69, 5-1-71, 6-26-73 (White, Brown \& Co.).

${ }^{4}$ Dun \& Co., Boston: 16.3(85), 7-2-77 (J.' S. \& E. Wright \& Co.).

7 Amory A. Lawrence to Amos A. Lawrence, 1877, July 3, 1877, A. A. Lawrence Papers.

${ }^{48}$ Hilliger, Talcott, 92; Ewing and Norton, Broadlooms, 83, 94, 141. 
selling costs, and part of these costs was charged to the mill in addition to commissions. Just what the commissions were meant to cover was a matter of agreement between the mill and the commission house. Second, even where the type of such an agreement is known, its economic significance still depends upon the internal structure of the commission house. For example, while an agreement may tell us that commissions should exclusively cover the earnings of partners' net of employees' salaries, it does not tell us whether the partners left most of the work to be done to salaried employees or whether new partners were admitted and paid by a share in profits out of commissions.

In order to be on safer ground we turn again to the actual payments of the Cocheco Manufacturing Co. to Lawrence \& Co. Adding the figures for commissions to sub-agents (Table 1, column $\mathrm{C}$ ), the salaries of employees (column D), and the commissions paid to partners (column A), we sum the total monthly payments on commissions and salaries (column G). The last are then related (column J) to the gross wholesale value of sales (column $\mathrm{H}$ ).

This ratio (column $\mathrm{H}$ ), between total payments on commissions and salaries and the monthly wholesale value of sales, is considered as the actual price for the package of selling services provided by the selling house. Our series for this price from 1849 to 1883 is not necessarily representative of a general price movement. Shortrun fluctuations and sudden shifts in the price level, like that from 1869 to $1870-1871$, can be attributed to particular qualities of the two individual firms. The package of services provided by Lawrence $\&$ Co. may have changed over time in an unrepresentative way and hence affected its price. But if we hesitate to take this particular price series as being representative of a general trend, we can at least say that the general trend as reflected in casual quotations of formal commission rates is confirmed in the one case for which we have solid data: the actual price paid by the Cocheco Manufacturing Co. for the services provided by the commission house was as high in the 1870's as it was in the 1850's.

We take for granted that the transportation service and the bookkeeping service did not assume a greater share in the total price of all services at the end than at the beginning of our period. As to the price of the selling service, it might well have increased with the beginnings of more aggressive selling. ${ }^{49}$ We were not able to associate the earnings of an individual salesman with as clearly

9 Increasing importance of traveling agents may have affected selling costs. But it was the jobbers who mainly employed the commercial travelers in our period. Cole, American Wool Manufacture, 292; Ewing and Norton, Broadlooms, 84, 94, 136, 152. 
identified a bundle of services in the 1870's as we were in the 1850's. The only later evidence we have for the earnings of sub-agents, who supposedly were predominantly engaged in bringing about contact with buyers, is taken from rather impressionistic reports of R. G. Dun \& Co. Taken as a whole, the reports convey the idea of only a limited financial success among sub-agents: Woodbury \& Foss were reported by 1881 to "make a living" without accumulating; and by 1885 to "barely make a living;" C. S. Bartlett \& Co. cleared $\$ 3,000$ in commissions in 1876 and were said to "make a good living;" Maxwell Lowry was "doing a good commission business" by 1875 , but eight years later R. G. Dun \& Co. found that it "must be close work for him to make a living;" C. J. Davis by 1886 was making "Just about . . . a living." 50

Of course, "to make a living" was a phhrase indiscriminately employed by reporters who knew nothing specific. But we learn something about the general image associated in the mind of the reporter with sub-agents as a group; a dramatic rise in sub-agents' earnings would have affected this image somehow. And nothing short of a dramatic rise would have made the selling service account for more than one-half of the price of the entire package of services.

\section{The Value of the Fabric-Advisory Service}

The ability of a commission house to give advice on the choice of fabrics naturally took many forms, and shades in the quality of advice led to a close affiliation of some houses with certain mills. Unlike financial aid or credit information, advice on the choice of fabrics was not easily standardized. It took specialized experience, well-established channels of information, and an individual capable of integrating this information into a vision of coming developments. A house of old standing in a particular field, with the right man at the right place, could offer advantages to a mill not quickly matched by other houses.

If a house thus found itself in a sheltered position, monopolistic profits were likely to persist over time. These profits are hardly measurable except as a residual, that is, with all the difficulties involved before. What may be determinable is the price a commission house had to pay on the special skill of formulating and shaping the advice if the advice was furnished by a particular individual, a

50 Dun \& Co., Boston: 12.427(71), 7-11-81, 3-26-85 (Woodbury \& Foss); 15.176 (84), 11-20-76 (Bartlett \& Co.); 2.848(70), 11-10-75, 2.941(70), 2-16-83 (Lowry); 9.428(78), 3-18-86 (Davis). 
"prophet of fashion." 51 If such an individual could be identified and his earnings unambiguously associated with this special skill, one would get a lower limit for the value of the fabric-advisory service, a figure for the cost element included in the price of the service.

Of course, one would like to avoid the pitfalls involved in looking at the distribution of the net earnings of a commission house among its partners and in taking the share of each partner as a competitive market price for his personal services. A share could include profit and rent elements; it was fixed by agreement hardly responding to changes in a partner's achievements; social considerations and family relationships may have had a greater influence on it than economic factors. In only one situation of the history of Lawrence \& Co. does a share in earnings seem to reflect the economic significance of the specific function fulfilled by a partner. This moment of truth came with the admission of a former employee of a distant firm, a man without means who was not a social peer of the older partners, and with an unusually high reward for his future contributions to the firm's success. Let us see how this situation came about and what it meant.

In 1865, Lawrence \& Co. took over a new account and started selling for the recently incorporated Arlington Woolen Mills, later Arlington Mills. The Arlington Woolen Mills started out producing woolen fancy shirtings, flannels, and felted goods. After 1866, it went into worsted and cotton-warp dressgoods. Selling terms in the mid-1870's granted the commission house a commission of $2 \frac{1}{2}$ per cent on the sales proceeds and full reimbursements for expenditures on freight, cartage, labels, telegrams, and insurance. Yearly commissions of $\$ 25,000$ on a sales volume of $\$ 1,000,000$ were thus to cover general commission house expenses like store rent, to the amount of $\$ 9,500$, and the $\$ 8,000$ paid out as salaries to two employees dealing with Arlington fabrics. This left a profit of $\$ 7,500$ to the partners. ${ }^{52}$

We are informed on the functions fulfilled by the salaried employees working on Arlington goods by two statements. The first is a letter of recommendation of 1871 introducing Webster, one of the employees in question, and saying: "I doubt if anyone in this country knows so much about all descriptions of worsted goods as

51. Berger, Pacific Mills, 15.

52 E. Everton Foster (ed.), Lamb's Textile Industries of the United States (2 vols., Boston, 1916), I, 445; "Memo of an agreement between Messrs. Lawrence \& Co. \& the Arlington Woolen Mills, Sept. 1, 1874," statement on financial affairs of Arlington Mills, March 16, 1875, A. A. Lawrence Papers. 
him . . . I do not know of anyone, so far as I can judge, who would be more capable to superintend the manufacture of worsted goods, order styles, and make sales, than him." Obviously, Webster was expected, in addition to making sales, to watch the market and guide production. The second statement concerns the other employee, M. H. Dorman, who, by 1873 , was complaining about having too little "influence on the management of the production." ${ }^{53} \mathrm{He}$, too, apparently formerly had a say in preparing the goods. Thus, the salaried employees attended to problems of styles and production decisions and received part of their salary for doing so.

In sharp contrast to their role in the administration of the Cocheco Manufacturing Co. the partners apparently did not interfere with production problems of the Arlington Woolen Mills. For one thing, they all were not acquainted with the specific problems of woolen manufacture and had to leave the new problems to new employees. Also, the mill was ably managed by its treasurer, William Whitman, who held office with rare success from 1867 to 1902 . There was, thus, no need for the kind of entrepreneurial leadership Amos A. Lawrence was capable of offering. But the mill needed money, and supplying it with financial aid appears to be sufficient explanation, in the first stage of the development of the mill, for the commissionhouse partners' earnings. The financial foundation of the Arlington Woolen Mills was very weak. As late as 1875 , the paid-in capital amounted to $\$ 200,000$ and accumulated profits to $\$ 258,000$, a guarantee reserve for prospective losses on sales included. These funds hardly covered the fixed assets: the book value of real estate, buildings, machinery, and so on amounting to $\$ 439,000$. The entire working capital of $\$ 500,000$ had to be provided by outside parties; to a large extent by the commission house. ${ }^{54}$

In the late 1870 's the relative importance of the services performed by the selling house to the mill changed, and by 1882 the change became feasible in terms of profit distribution. We have referred to the increasing availability of short-run funds in the 1870's. At the same time, the Arlington Woolen Mills increased its capital stock to $\$ 500,000$ in 1877 and $\$ 750,000$ in 1880 . A series of spectacular dividend payments, compared with what was usual in the textile industry at the time, of 10 per cent yearly from 1878 to 1881 also improved the mill's credit standing. In fact, by 1879 Arlington's treasurer refused to sell his paper to Lawrence \& Co.

${ }^{3}$ G. Brewer to Amos A. Lawrence, June 26, 1871, M. H. Dorman to Amos A. Lawrence, January 21, 1873, A. A. Lawrence Papers.

5 : Statement of the condition of the Arlington Mills, November 30, 1875, ibid. 
at a discount rate of 4 per cent "saying he could do better on the street." 55

In April 1881, then, the mill must have felt independent enough to raise some problems with the commission house and to suggest solutions which, at first sight; seemed to aim at breaking up the relations between Arlington and Lawrence \& Co. $^{56}$ What was at stake was the ability of the commission house to perform the fabricadvisory service. This ability was challenged by Whitman in a memorandum of May 9, 1881; at the same time the need for advice was made clear: ${ }^{57}$

The machinery now at the mill enables me not only to obtain a larger product, but to vary it to meet the constantly changing preferences of customers. The prospective demands of our business indicate the necessity for greater variety of product - smaller quantities of each - higher quality of texture - the exercise of taste and knowledge of the wants of buyers, to a greater degree than heretofore.

I cannot manage this to the best advantage without skilled and intelligent aid. Prominent amongst these requirements is to have persons quick to appreciate any indications of a coming change, either in sorts or colors of the goods, and to suggest the most promising to be made for the immediate future. Such persons can only obtain the requisite skill and knowledge by constant intercourse with buyers and by possessing their confidence. The aid that $I$ require is that of the practical goods merchant. I do not need ... manufacturing knowledge, but commercial sagacity to guide us to the probable needs of the market, and to sell the goods . . . Now, neither in Boston nor in New York have $I$ the aid that I require, i.e., such a person as I have already described to handle the goods, and be responsible for doing so ... . New York, our largest outlet for goods, needs, I think, immediate care.

Having given this perceptive description of the service he expected his selling house to perform, the mill's treasurer pointed to the man he wanted placed in charge of the selling job in New York: Alfred Ray, hitherto employed in Chicago by Marshall Field \& Co. ${ }^{58}$

Ray soon became a partner of Lawrence \& Co., responsible for "the control of the Arlington, absolute control ... Prices and style" - so agreed the partners - "we should be second." 59 If there is any doubt left as to whether Ray was primarily expected, in terms of the treasurer, to "sell the goods" or "to guide us to the probable needs of the market," we find evidence for the dominance of the latter function: Ray had not been a salesman or a sales manager with Marshall Field \& Co. but purchasing manager of the dress

\footnotetext{
\& Amory A. Lawrence to Amos A. Lawrence, April, 1879, ibid.

5 Lawrence \& Co. to Whitman, April 30, 1881, ibid.

57 Memorandum of Mr. Whitman about business, May 9, 1881, ibid.

6s Dun \& Co., Chicago: 18.255(44), 11-29-78.

50 Amory A. Lawrence to Amos A. Lawrence, December 1, 1881, A. A. Lawrence Papers.
} 
goods department. ${ }^{60}$ In that capacity he had become expert in judging demand rather than in making buyers buy.

What did Lawrence \& Co. pay for the services of the new man? Ray asked for a yearly salary of $\$ 20,000$. He was guaranteed this amount and promised, in addition, one-quarter of the increase of profits of 1883 and 1884 over the profits of 1882 . His actual share in profits for the first eleven months (January 1-November 30, 1882 ) amounted to $\$ 18,333$ and to $\$ 24,000$ for the first full year. Profits from commissions increased after Ray had joined the firm. But of course the older partners' share in these profits declined. They were credited with $\$ 12,000$ in $1879 ; \$ 9,000$ in 1880 ; and $\$ 14,000$ in 1881. The new arrangement left them with $\$ 6,000$ in 1882 and with $\$ 7,000$ in 1883: their earnings from the Arlington Woolen Mills were roughly cut in half. ${ }^{61}$.Incréase in relative importance of a particular kind of human skill had forced them to transfer profits to the scarce factor, unless they were prepared to quit the Arlington business which they no longer were able to keep through financial ties.

\section{Conclusions}

The general hypothesis and model suggested that much money was paid by the mills for the fabric-advisory service of the commission houses - perhaps even one-half of the cost of the latter's whole package. The case approach shows that in a particular situation a member of a commission house was paid an extremely high salary (and profit-sharing) for providing that service; indeed, his salary was three times that of the recompensation earned by the mill's top manager, its treasurer.

The strong position of the commission house in the woolen and cotton industries was not just a residual of mercantile capitalism. The characteristics of product innovation in our period and in our industry - continuous adjustment of production to a flow of information on short-run changes of the market - tied up important entrepreneurial activities with an agency close to the market. Not much more was left at the mill in many cases than the trade-school type of technical management in "command of the intricacies of textile production" as characterized by Navin. ${ }^{62}$ And the character-

0 Dun \& Co., New York City: 3.1283(221), 1-5-82; Chicago: 18.255(44), 11-29-78.

n1 Lawrence \& Co., to Alfred Ray, July 20, 1881, A. A. Lawrence Papers; waste book, Mason \& Lawrence Papers.

62 Thomas R. Navin, Jr., "Innovation and Management Policies: The Textile Machinery Industry: Influence of the Market on Management," Bulletin of the Business Historical Society, XXV (March, 1951), 15-30. 
istics of entrepreneurial activity only reflected the basic task with which the industries were confronted: adjustment of a technically mature apparatus to the growing sophistication of a society able to pay for more than the basic needs. Thus, the marketing man appears as the true leader in a process of permanent open-ended change, competitive pressure on his back and profits before him as a reward for a creative idea; profits for the mills, to be sure, but he would get the benefit from them.

\section{Appendix to Tables}

The figures of Table 1 are calculated on the basis of entries in the waste books of Mason \& Lawrence (later Lawrence \& Co.). Column $\mathrm{H}$ gives for each commercial year (December 1-November 30) the average of the monthly gross wholesale values of sales of Cocheco prints effected by the commission house. Column A gives for each year the average of monthly commissions paid by the commission house to the mill; these figures are calculated as percentages of the gross wholesale value of sales in column $\mathrm{H}$ on the basis of the formal commission rate. The formal commission rate was $1 \frac{1 / 2}{2}$ per cent until May 31, 1849, 1//4 per cent from June 30, 1849,

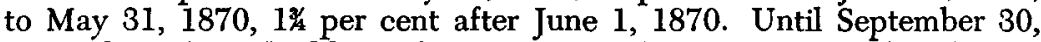
1858, the mill paid additional commissions of $\frac{1}{2}$ per cent on sales effected outside of Boston to the commission house. For each year the average of monthly additional commissions has been included in Column A.

Column $\mathrm{C}$ shows for each year the average of monthly commissions paid by the mill to the sub-agent in New York from 1849 to May 31, 1859, and after June 1, 1859, the share of the Cocheco Manufacturing Co. as actually fixed by the commission house in the salary of an employee of the commission house in New York. Column D gives the share of the Cocheco Manufacturing Co. in salaries paid to employees of the commission house in Boston. Salaries of employees were charged according to the accounting system of the commission house to a general expense account and the mill accounts were charged for a share in general expenses. On the assumption that each mill's share in general expenses went in equal proportions on the different expense items, we calculated that percentage of general expenses charged to the Cocheco Manufacturing Co. which was paid out as salaries to employees, for four two-year periods: December 1, 1849 to November 30,1851, 1859/61, 1869/71, $1879 / 81$. This percentage figure was quite stable, 53 per cent on the average for the first, and 47 per cent, 47 per cent, and 56 per cent for the other three two-year periods. For each year we took that percentage figure as the basis for the calculation of the payments of the Cocheco Manufacturing Co. on salaries which comes closest chronologically to the particular year. The average monthly value of the share of the Cocheco Manufacturing Co. in total general expenses for each year was calculated as a moving average of the values for May and November of three years.

Table 2 is derived from R. G. Dun \& Co.'s credit rating ledgers for Boston. The reports describe the negotiable instruments in question 
simply as "paper" in most cases and occasionally as "acceptances" or "endorsements" without specifying their particular character. This paper may have included the following four types: single-name promissory notes issued by the commission house; two-name promissory notes issued by the manufacturing firm and endorsed by the commission house; trade bills used by customers for payment and endorsed by the commission house; drafts drawn by the commission house on buyers. These four types are lumped together under the heading of "commercial paper." This term used here does not imply that the paper was only sold in the street; it may have been sold also to banks. 